\title{
Edice Romana Jakobsona s otazníky
}

\author{
Ivo Pospíšil (Brno)
}

Jindřich Toman (ed.): Angažovaná čítanka Romana Jakobsona. Články, recenze, polemiky 1920-1945

a Moudrost starých Čechů. Praha: Univerzita Karlova, nakladatelství Karolinum, 2017. 298 s.

ISBN 978-80-246-3673-3.

Památce Ladislava Matějky věnoval užitečnou edici publicistických prací Romana Jakobsona Jindřich Toman. Užitečnou $\mathrm{v}$ tom smyslu, že každé takové vydání je cenné, nebot pomáhá zpřesnit a koncentrovat odkaz lingvisty a literárního vědce, fonologa, versologa, historika, kulturologa a kulturního a politického činitele. Prvním otazníkem je sám název, zejména kulaté slovíčko „angažovaný“. To je třeba precizovat a historicky konkretizovat, tedy angažovaný pro co a jak. $\mathrm{O}$ to se Toman již výběrem textů pokusil, ale podle mého soudu stále jen málo výrazně. Ale i to nutno ocenit ve vztahu $\mathrm{k}$ tomu, jak jednostranně a schematicky, mlhavě se Jakobson z tohoto aspektu u nás dříve vykládal. Je sice pravda, že publikované texty jsou většinou známy, ale je třeba je někdy složitě dohledávat v různých periodikách či dokonce novinách a časopisech a některé jsou tu v takové edici publikovány poprvé.

Editor svou knihu rozdělil do několika oddílů. Nejrozsáhlejší se nazývá Články, recenze, polemiky 1920-1945 a má pododdíly, a to Avantgarda a veřejnost, Nová věda, Emancipace Východu, Konstrukce cyrilometodějství, Pohledy z Ameriky. Jako postskriptum následuje Př́ipitek české zemi z konstantinovského sympozia v Praze (1969) a nakonec nejrozsáhlejší svazek Moudrost starých Čechů, fakticky v stereotypním vydání. Doslov se jmenuje Lingvistova cesta na veřejnost a jako pendant je tu nepř́lišs podařené anglické resumé.

Cenné je v Tomanově doslovu právě to, že přece jen poněkud otvírá dvířka k Jakobsonovu ideovému vývoji a $\mathrm{k}$ proměnám jeho ideologických a politických názorů, zejména v období první Československé republiky. Zde se v českém prostředí stále retušuje zejména ideová a politická pozice Romana Jakobsona, ovšem také v souvislosti se záměrným znejasňováním ideologického postavení a objektivní společenské pozice avantgardy, Pražského lingvistického kroužku apod., pokud to lze vůbec přesněji zobecnit, nebot jednotlivé osobnosti se přirozeně lišily. A to, co dřive bylo samozřejmé, tedy schopnost porozumění dobovému kontextu, jeho sémantice, znakům, symbolům a mýtům - to vše je dnes už problémem. Východiskem je návrat ad fontes. Retušování má svůj vývoj zasahující i do československého poválečného vývoje i konkrétně do let 1968-69 - obvykle se prezentují podle dobového diktátu. Oblíbenou metodou je právě „vyřezávání“ z konkrétního dobového rámce. K tomu se ostatně sám Jakobson vrací v uvedeném přípitku z roku 1969, kde ř́ká, že přišel do Prahy jako vyslanec „čisté revoluce“, vyjádření snad upřímné, ale vyvolávající další otázky. K Jakobsonově osobnosti a jeho vývoji se nyní vracejí další badatelé, například Roman Mnich a Oksana Blaškiv ${ }^{1}$, ale novější literatura je

1 BLASHKIV, Oxana - MNICH, Roman: Dmitrij Čiževskij versus Roman Jakobson. Redakcja tomu: Roman Bobryk. Opuscula Slavica Sedlcensia, tom VI, Uniwersytet Przyrodniczo-Humanistyczny w Siedlcach, Wydzial Humanistyczny, Instytut Neofilologii i Badań Interdyscyplinarnych, Instytut Kultury Regionalnej i Badań Literackich im. Franciszka Karpińskiego. Siedlce, 2016. Viz naši recenzi: Dỉkladná revize, srovnáni a rehabilitace jako záloha pro budoucnost. Novaja rusistika 10, 2017, č. 1, s. 98-103. Viz také monografii spoluautorky o D. Čyževském: BLAŠKIV, Oxana: Češka i slovacka kultura v žytti ta naukovij spadščyni Dmytra Čyževśksoho. Litteraria Sedlcensia, tom VI Siedlce, 2010. Práce historiků někdy pomíjejí odborné filologické souvislosti Jakobsonovy tvorby, bez nichž nelze pochopit nic podstatného, viz např. jinak zajímavou stat', na niž mě upozornil G. Maiello: KONEČNÝ, K. - POLLEY, I.: Roman Jakobson and Czechoslovakia in the Context of Czechoslova-Soviet Relations 1920-1969. 
editorovi bud' nedostupná, nebo je pod jeho rozlišovací schopnost - a to je někdy opravdu škoda.

Na počátku stojí článek o vědě a novinách: zde Jakobson dosvědčuje, že pochopil již tehdy úlohu médií v propagaci výsledků vědecké práce. Že byl přívržencem bolševické revoluce a sovětského režimu svědčí již jeho článek z roku 1919 o tzv. umělecké propagandě i jeho rozhovory, když už byl v Praze, a jeho tehdejší malá citlivost k českému prostředí právě ve dvacátých letech 20. století, jak jsme ji prezentovali na textech proslulých vot separat k jeho kontroverzní brněnské habilitaci. ${ }^{2}$

Z oddílu Avantgarda a veřejnost asi nejvíce zaujme nejznámější článek o básnickém umprumáctví a živnostnictví, snad i odpověd' na anketu Bloku z roku 1938: ukazují Jakobsona jako politicky zcela vyhraněnou osobnost. Také oddíl Nová věda je dobrou př́lohou jeho vědeckých prací vznikajících v Československu, i když ani tu Jakobson, ještě v době své brněnské habili-

In: Modern Greek Studies Yearbook. A Publication of Mediterranean, Slavic and Eastern Orthodox Studies. Minneapolis, University of Minnesota, vol. 30/31, 2014/2015, s. 145-170. Někdy se objevuje objevené a vytváří se bludný kruh.

2 Voty separaty se zevrubně zabýval Miloš Zelenka ve studii Několik poznámek $k$ Jakobsonově habilitaci na Masarykově univerzitě v letech 1932-1933. Slavia 61, 1992, s. 74-81. Viz také jeho spoluautorství snad nejlepší studie o Romanu Jakobsonovi, která kdy u nás a možná vůbec vznikla (spolu s Tomášem Hermannem) v jeho a Hermannově invenční edici Moudrost starých Čechů. Komentovaná edice s navazujici exilovou polemikou. Eds. Tomáš Hermann - Miloš Zelenka. Praha: Ústav pro soudobé dějiny AV ČR - Pavel Mervart, 2015. Viz také naši interpretaci Razance a citlivost: K fenoménu Stredni Evropy $v$ meziválečném obdobi (tři vybraná vota separata $k$ brněnské habilitaci Romana Jakobsona). In: Slovensko-české vztahy a súvislosti. Zborník referátov a koreferátov z medzinárodnej vedeckej konferencie Slovensko-české vztahy a súvislosti, ktorá sa ukutočnila 26.-27. 10. 2000 v Bratislave. Organizátor konferencie: Katedra slovanských filológií FiFUK v Bratislave v spolupráci s Ústavom slavistiky FFMU v Brne, Slovenská rada Združenia slovanskej vzájomnosti v spolupráci s Českou koordinačnou radou Spoločnosti priatelov s národmi východu. Bratislava, 2000, s. 49-60; něm. verze Rasanz und Feingefühl: Zum Phänomen Mitteleuropa in der Zwischenkriegszeit. In: Litteraria Humanitas XI. Crossroads of Cultures: Central Europe, Kreuzwege der Kulturen: Mitteleuropa, Křižovatky kultury: Střední Evropa, Perekrestki kul'tury: Srednjaja Jevropa. Brno: Masarykova univerzita, Filozofická fakulta, Ústav slavistiky, 2002, editor: Ivo Pospísili. tace podle zjištění klasického filologa Františka Novotného sovětský státní př́slušník, nepouští ze zřetele tezi o možné spolupráci SSSR a tzv. Západu, zejména ve vědecké oblasti (publikováno v čas. Země sovětů). Bylo to ostatně v roce podepsání československo-sovětské spojenecké smlouvy (1935), na dohled stalinské ústavy, považované na Západě mezi intelektuály za nejdemokratičtější na světě.

Jeho medievistické zájmy shrnuje oddíl o emancipaci Východu a z faktografického hlediska je nejzajímavější partie z jeho amerických textů, včetně skandální recenze románu Egona Hostovského Sedmkrát v hlavní úloze. To jako by dokládalo lidskou a společenskou strategii a taktiku obou autorů v emigraci: oba mají talent být úspěšní a činit tak, aby tedy šli s mainstreamem; Hostovský by to jistě dokázal, ale programově odmítal, Jakobson nikoli. Roman Mnich a jeho spoluautorka Oxana Blaškiv charakterizují ve své nejnovější knize (viz pozn. 1) Jakobsona - na rozdíl od smolaře, těžce se probíjejícího Dmytra Čyževského - jako muže štastného osudu; tomu je však třeba umět vyjít vstříc a Jakobson i svou spoluprací s tiskem a schopností utilitárního hodnotového posunu tento postoj dosvědčuje. Alespoň počátkům složitosti jeho situace a motivace se autor sám věnuje již ve své studii z roku $1996 .^{3}$

K pracím, jež spekulují o jeho politickém postoji a jeho pozici vưči SSSR a USA, netřeba nic podstatného dodávat, protože to není vzhledem $\mathrm{k}$ významu Jakobsonova vědeckého a publicistického díla důležité. Do Československa se již od roku 1969 nevrátil. V roce 1968 se v Praze zúčastnil VI. mezinárodního sjezdu slavistů a byly mu uděleny čestné doktoráty Univerzity Karlovy a Univerzity Jana Evangelisty Purkyně v Brně, dříve i nyní Masarykovy univerzity; video s jeho inauguračním projevem je dostupné na internetu, ${ }^{4}$ bohužel informace uvedená v archivu

3 TOMAN, Jindřich: „Balancovat v nepredstavitelných situacích": poznámky k českým létiom Romana Jakobsona. Slovo a slovesnost 57, 1996, s. 226-240.

4 http://www.ceskatelevize.cz/zpravodajstvi-brno/ extra/192007-exkluzivni-video-nevitany-vitany-svetovy-lingvista-roman-jakobson-v-brne. Právě v tomto inau- 
ČT v Brně je nepravdivá, nebot předpokládá, že Jakobson odešel ze SSSR nedobrovolně jako politický emigrant: „[...] do někdejšiho Československa a později $i$ do Brna př̌šel vlastně trochu z donuceni v roce 1920. Utikal ze Sovětského svazu, kde jeho názory té době nekonvenovaly. Právěv malé středoevropské zemi však podle suých slov prožil jedno z nejkrásnějších obdobi svého života." Do SSSR jezdil před rokem 1968 poměrně často, poté jen jednou; podle údajů z otevřených zdrojů byl v SSSR na pozvání Akademie věd SSSR v roce 1956 (17.-25. 5.) na zasedání Mezinárodního komitétu slavistů, jenž připravoval IV. mezinárodní sjezd; sjezdu se pak v Moskvě zúčastnil ve dnech 1.-10. 9. 1958; na zasedání MKS byl opět v roce 1962; 3.-10. 8. 1964 byl v Moskvě na VII. mezinárodním kongresu etnologických a antropologických věd, 4. 8. - 8. 9. 1966 byl v SSSR nejdéle, a to v Moskvě na mezinárodním kongresu psychologie, v Leningradě na semináři o tvorbě a recepci řeči, na Letní škole sémiotiky v Tartu, zúčastnil se oslav 800. jubilea Šoty Rustaveliho v Tbilisi a přednášel v moskevských institutech slavistiky, ruského jazyka a národů Asie a byl zde ještě ve dnech 17.-24. 8. 1967; po roce 1968 jen jednou, a to 29. 9. - 4. 10. 1979 v Tbilisi.

Když se v roce 1993 pořádala v Brně mezinárodní konference věnovaná jeho osobnosti, navštívil jsem tehdy (1993) velvyslanectví USA v Praze, abych jeho představitele pozval. Od kulturní atašé jsem se dověděl, že Jakobson prý vůbec nebyl občanem USA - nicméně velvyslanectví poslalo účastníkům konference pozdravný dopis. Takže řada okolností života a díla velkého ruského filologa $\mathrm{s}$ přesahem $\mathrm{k}$ jiným vědám a s obrovským vědeckým potenciálem a rozpětím zůstává dodnes ne zcela vyjasněna.

guračním proslovu se zmínil o knížečce, kterou mu na rozloučenou na jaře roku 1939 vydali jeho studenti (Pozdrav a dikiovdání, Brno 15. 3. 1939). Ten den měl Roman Jakobson držet k studentům poslední přednášku na Masarykově univerzitě, ale ta se v důsledku německé okupace nekonala. Jak však Jakobson v inauguračním projevu uvedl, stala se podkladem jeho americké knihy Moudrost starých Čechri. Zdá se tedy, že Jakobson měl k této knize i jejímu názorovému vyznění - nehledě na polemickou odezvu - zvláštní vztah, což by nepřímo potvrzovalo dominantní ideu studie Hermannovy a Zelenkovy ve výše uvedené nové, komentované edici.
At̉ již se editor dopouštěl místy nepřesností a ty můžeme různě hodnotit a přikládat jim tu větší tu menší váhu, nutno ocenit jeho výběr textů, to, že se nebál narušit obvyklé české retušování Jakobsonova názorového vývoje, že se snažil vše vidět v souvislostech a historicky, méně již jeho znalost novější odborné literatury; kromě textů, jež sám uvádí, a těch, které jsme mimovolně uvedli, se Jakobsonem zabývala řada badatelů - chybějí i některé edice ${ }^{5}$, např. ta, kterou uspořádala Alena Morávková a kde se uvádí i přípitek z roku $1969^{6}$. Nejproblematičtější je zařazení edice Moudrost starých Čechů už proto, že je v podstatě stereotypní: o Jakobsonově postoji $\mathrm{k}$ jejímu novému vydání v pozdější době víme, že byl ambivalentní, jak dokládá informace Iva Osolsobě publikovaná v brněnském sborníku k Jakobsonovu výročí. ${ }^{8}$ Poněkud stranou zůstalo Brno se svou Masarykovou univerzitou, jež Jakobsonovi zajistila zaměstnání a vědeckou kariéru - nehledě na argumentovaný odpor ze strany filologických tradicionalistů. Novou edici Jakobsonových textů lze tedy ocenit v zásadě kladně, ale s otazníky.

5 Viz naši recenzi na: JAKOBSON, Roman: Formalistická škola a dnešni literárni věda ruská. Brno, 1935. Editor Tomáš Glanc. Praha: Academia, 2005. 321 s. In: Stil 4, Beograd, 2005, s. 403-405.

6 JAKOBSON, Roman: $Z$ korespondence. Sestavila Alena Morávková. Praha - Litomyšl: Paseka, 1997; viz naši recenzi: Živý odkaz. Slavica litteraria X 2, 1999, s. 89-90.

7 Nová, již výše zmíněná, skvěle komentovaná edice s rozsáhlou monografickou studií o R. Jakobsonovi je sice Tomanovi známa, ale nekonfrontuje se s ní; viz: JAKOBSON, Roman: Moudrost starých Čechů. Komentovaná edice s navazujici exilovou polemikou. Eds. Tomáš Hermann - Miloš Zelenka. Praha - Červený Kostelec: Ústav pro soudobé dějiny AV ČR - Pavel Mervart, 2015. Viz naši recenzi: Dilo překvapivě aktuálni, zrcadlici dějiny, dobu i osobnost: idea národa, nebo demytizujici realistické prázdno? In: Kontexty literární vědy V. Eds: Ivo Pospíśil - Miloš Zelenka. Brno: Literárněvědná společnost při AV ČR, Tribun EU, 2015, s. 143-148.

8 Litteraria Humanitas IV, Roman Jakobson. Odpovědný redaktor Miroslav Mikulášek, výkonní redaktoři Danuše Kšicová a Ivo Pospíšil. Brno: Masarykova univerzita, 1996. 
prof. PhDr. Ivo Pospíšil, DrSc.

Ústav slavistiky

Filozofická fakulta, Masarykova univerzita

Arna Nováka 1, 60200 Brno, Česká republika

ivo.pospisil@phil.muni.cz 